\title{
Comparative structure of the macro- zooplankton/micronekton communities of the Subtropical and Antarctic Polar Fronts
}

\author{
E. A. Pakhomov, R. Perissinotto, C. D. McQuaid \\ Southern Ocean Group, Dept of Zoology and Entomology, Rhodes University, PO Box 94, Grahamstown, 6140, South Africa
}

\begin{abstract}
The composition, distribution, abundance, biomass and size-structure of macroplankton/ micronekton communities at the Subtropical Convergence (STC) and the Antarctic Polar Front (APF) regions were investigated during the South African Antarctic Marine Ecosystem Study (SAAMES II, January-February 1993; SAAMES III, June-July 1993). A total of 115 and 32 macroplankton/micronekton species were found in the epipelagic zones of the STC and APF, respectively. Cluster analysis based on species composition indicated the occurrence of 3 different plankton communities: one in the STC region, another to the north of the APF and the third to the south of the APF. Although the APF and the STC were investigated in different seasons, average abundance and biomass were similar in both regions. Tunicates, euphausiids, decapods and myctophiid fishes dominated the total stock of the 2 frontal regions, in terms of both abundance and biomass. Both fronts exhibited considerable fluctuations in the abundance and biomass levels which appeared to covary with the spatial distribution of the phytoplankton stock in the area. The dominant size-classes were composed of a small group of 5 to $30 \mathrm{~mm}$ siphonophores, tunicates and euphausiids and a larger group of 40 to $80 \mathrm{~mm}$ euphausids, chaetognaths, vertically-migrating decapods and myctophiid fishes.
\end{abstract}

KEY WORDS: Subtropical Convergence · Antarctic Polar Front · Macrozooplankton - Micronekton Biomass $\cdot$ Abundance $\cdot$ Taxonomy Community structure

\section{INTRODUCTION}

The Southern Ocean is subdivided into several thermohaline zones by 4 major circumpolar fronts (Deacon 1982, Lutjeharms \& Valentine 1984, Lutjeharms 1985) which exhibit enhanced biological activity, compared to the adjacent waters (Allanson et al. 1981, Lutjeharms et al. 1985, Chapman et al. 1987, Laubscher et al. 1993).

The Subtropical Convergence (STC), dividing the subtropical and subantarctic waters, forms one of the strongest horizontal temperature gradients of this ocean. North of this, the region directly south of Africa is exposed to the influence of the Agulhas Current system. The interaction of the Agulhas Retroflection Current (ARC) with the northern border of the STC causes a high degree of variability in currents and meridional heat transport by warm-core eddies that often cross the STC (Olson \& Evans 1986, Chapman et al. 1987, Gor- don et al. 1987). The Antarctic Polar Front (APF), dividing the Subantarctic and Antarctic zones, is the second main circumpolar front in the Southern Ocean (Deacon 1982, Lutjeharms \& Valentine 1984).

Physical transport mechanisms, phytoplankton new production, grazing food chains and vertical migrations of zooplankton, provide the basis for the transport of fixed carbon into the deep ocean. This is known as the 'biological carbon pump' (Longhurst \& Harrison 1989). The oceanic fronts not only have a substantial influence on the total productivity of the pelagic subsystem of the Southern Ocean, they may also contribute significantly to the removal of large amounts of fixed carbon to deep ocean waters. In a recent model of the Antarctic ecosystem, Huntley et al. (1991) suggested that up to $80 \%$ of the net primary production may be consumed directly by the meso- and macrozooplankton. During the last decade, research activities in the Southern Ocean have increased rapidly and 
investigations on the macrozooplankton/micronekton component have been focused mainly on the community level. Neritic (Fukuchi et al. 1985, Tanimura et al. 1986, Tuker \& Burton 1990), marginal-ice zone (Hopkins et al. 1989, Hosie \& Stolp 1989, Lancraft et al. 1989, Siegel et al. 1992) and open oceanic communities (Hopkins 1985, 1987, Piatkowski 1987, Siegel \& Piatkowski 1990, Boysen-Ennen et al. 1991, Pakhomov 1991, Hosie 1994) in the different sectors of the Southern Ocean have been the subject of the most intensive investigations. However, the communities of the Subantarctic, the APF and the STC zones have been largely neglected and are still poorly known. Within these areas, only the waters around island masses have received some attention (Miller 1982a, b, 1985, Boden \& Parker 1986, Perissinotto \& McQuaid 1992, Pakhomov 1993a).

This study was, therefore, designed with the aim of improving the information on the composition, distribution, abundance, biomass and size-structure of the macrozooplankton/micronekton communities in the main frontal zones of the Southern Ocean.

\section{MATERIALS AND METHODS}

Samples were collected during 2 cruises of the South African Antarctic Marine Ecosystem Study (SAAMES) aboard the SA 'Agulhas' (Voyages 70 and 72). The first survey, SAAMES II, took place during the period 21 January to 4 February 1993 in the region of the Antarctic Polar Front (APF), between latitudes of $47^{\circ}$ and $53^{\circ} \mathrm{S}$ (longitude $0^{\circ}$ to $10^{\circ} \mathrm{E}$ ). On the second occasion, SAAMES III, during the period 25 June to 12 July 1993 . the work was carried out at the Subtropical Convergence (STC) in the region of the Agulhas Retroflection Current, between latitudes of ca $39^{\circ}$ and $44^{\circ} \mathrm{S}$ (longitude $10^{\circ}$ to $22^{\circ} \mathrm{E}$ ) (Fig. 1). During each cruise, three $36 \mathrm{~h}$ stations across the APF and the STC were undertaken in the middle, in the southern and in the northern vicinity of the frontal regions, respectively. At each station, trawls were carried out at regular intervals of ca 2 to $3 \mathrm{~h}$. In addition, in the region of the STC 3 transects through a warm-core eddy (WCE) were made with trawls at intervals of ca 8 to $12 \mathrm{~h}$ (Fig. 1). A total of 9 samples from the region of the APF and 30 samples from the region of the STC were collected and analyzed.

Macrozooplankton and micronekton were collected using a Rectangular Midwater Trawl (RMT-8) with a nominal mouth area of $8 \mathrm{~m}^{2}$ and mesh size of $4.5 \mathrm{~mm}$ (Baker et al. 1973). The volume filtered by the trawl was determined by multiplying the effective mouth area of the trawl by the distance travelled. This was calculated from the ship's speed and the period of

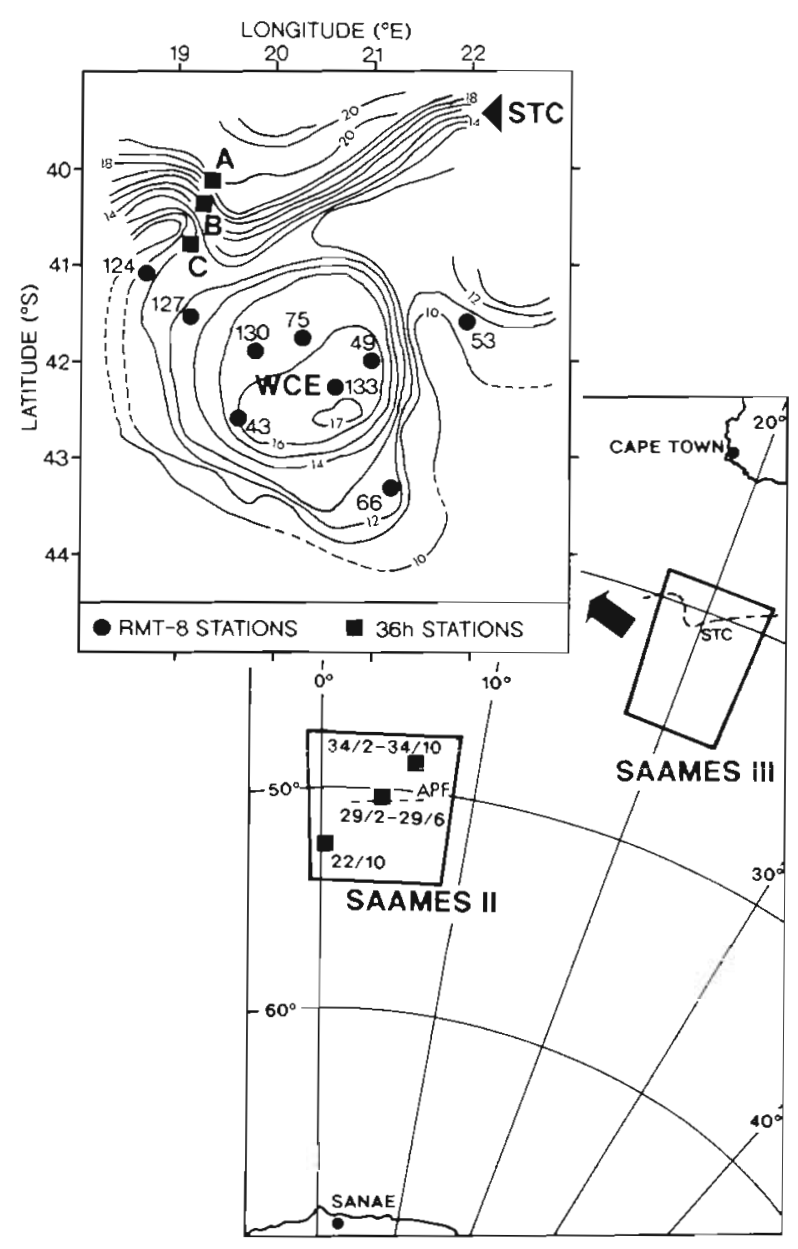

Fig. 1. Sea surface isotherms and macroplankton/micronekton stations occupied by the SA 'Agulhas' during JanuaryFebruary 1993 (SAAMES II) and June-July 1993 (SAAMES III adapted from Lutjeharms et al. 1994). STC: Subtropical Convergence; WCE: warm-core eddy. A: STC Stn A (from $84 / 1$ to $88 / 3$ ); B: STC Stn B (from 106/1 to $110 / 2$ ); C: STC Stn C (from 101/2 to $105 / 1$ )

trawling, after the trawl was opened in the water. In calculating the volume filtered, the effect of towing speed was also taken into account (Roe et al. 1980, Pommeranz et al. 1982). Towing speed varied between 1.5 and 4 knots. Usually, the trawl was towed obliquely between 0 and $300( \pm 100) \mathrm{m}$. The depth and the opening and closing of the trawl were controlled by a Universal Underwater Unit ( $\mathrm{U}^{3}$, Robertson et al. 1981). Samples were preserved in $4 \%$ buffered formalin and examined in the laboratory. Catches were sorted, counted and analyzed for taxonomic identification, body length (with an accuracy $=1 \mathrm{~mm}$ ) and displacement volume. The dry weight of the main macroplanktonic and micronektonic groups from the different hauls were obtained by oven-drying specimens for 36 h at $60^{\circ} \mathrm{C}$. 
A pre-calibrated $120 \mathrm{kHz}$ echo-sounder (Simrad EK500) was used for the detection of plankton acoustic backscattering. This was operated in conjunction with an echo-integrator with output on a colour printer. This gave a depth-stratified quantitative estimate of acoustic reflectivity $\left(S_{a}, \mathrm{~m}^{2} \mathrm{~nm}^{-2}\right)$ along the survey path every 30 min.

To compare the plankton communities from the APF and the STC regions, cluster analysis was carried out using Jaccard similarity index (Jaccard 1902) coupled with pair-group single linkage (nearest neighbour clustering):

$$
K_{J}=C /(A+B-C)
$$

where $K_{J}$ is the coefficient of similarity, $A$ and $B$ are the number of species in the respective areas and $C$ is the number of species common to the 2 areas. Data from all samples collected at the $36 \mathrm{~h}$ stations were pooled for the purpose of this analysis.

\section{RESULTS}

\section{Composition, abundance and biomass}

A total of 115 and 32 macrozooplankton and micronekton species were found in the epipelagic zone of the STC and APF, respectively (Table 1). The highest number of species (63) was recorded at Stn A, immediately north of the STC (winter), and the lowest (8) at Stn 22, immediately south of the APF (summer).

Selecting an arbitrary distance level of $31.5 \%, 3$ clusters describing sample groups of similar geographical origin were obtained (Fig. 2). Cluster 1 covered the STC region, while Cluster 2 included the centre of the $\mathrm{APF}$ and the area immediately north of it. Cluster 3 contained only 1 station, located immediately south of the APF. Very low coefficients of similarity 10.02 to 0.16) were obtained when APF and STC regions were compared. However, within the APF region coefficients of similarity ranged from 0.11 to 0.38 , and within the STC from 0.22 to 0.42 (Fig. 2).

In the APF region, tunicates and euphausiids dominated the catch and together accounted for $93.7 \%$ and $84.2 \%$ of total abundance and biomass, respectively (Table 2). Fishes constituted about $13 \%$ of the total biomass, although their contribution to total abundance was $\leq 1 \%$ (Table 2). At Stn 22 (Cluster 3) Euphausia superba was the most abundant species (Fig. 3C), with concentrations of 4.5 ind. $\mathrm{m}^{-2}$ and $475 \mathrm{mg}$ dry wt $\mathrm{m}^{-2}$. The most abundant species at Stns $29 \& 34$ (Cluster 2) tended to be Salpa thompsoni, which reached densities of up to 26.7 ind. $\mathrm{m}^{-2}$ and $325 \mathrm{mg}$ dry wt $\mathrm{m}^{-2}$ (Stn 29, Fig. 3C). This species contributed more than $80 \%$ to the total abundance and biomass. The euphausiids

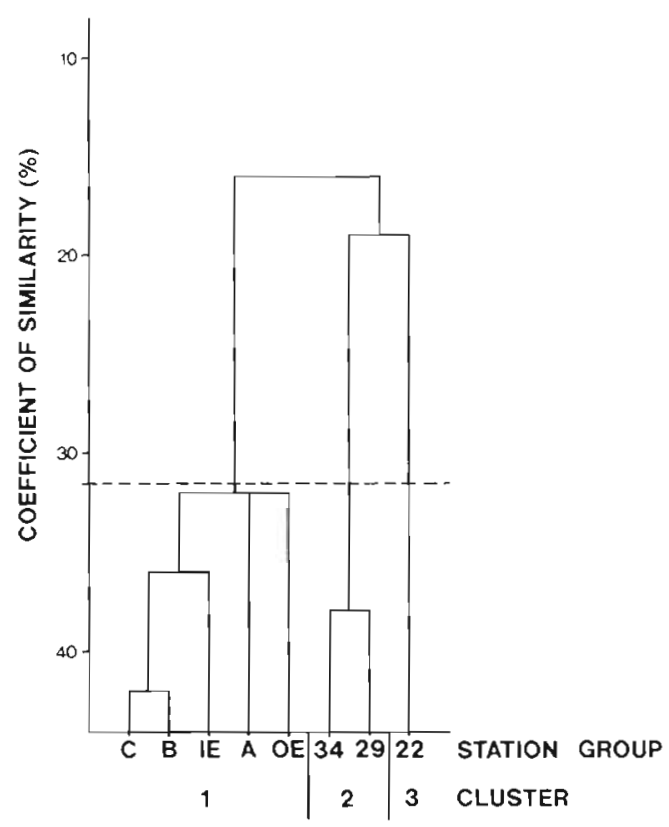

Fig. 2. Dendrogram based on similarity coefficients among RMT-8 samples according to macroplankton/micronekton species composition. A: STC Stn A; B: STC Stn B; C: STC Stn $C_{i}$ IE: inside warm-core eddy (Stns $43,49,75,130$ \& 133); OE: outside warm-core eddy (Stns 53,66, 124 \& 127); 22: APF Stn 22/10; 29: APF Stns 29/2 to 29/6; 34: APF Stns $34 / 2$ to $34 / 10$

Euphausia vallentini and E. triacantha were the next most abundant species in this zone (Fig. 3C). The nighttime sample of Stn 34 was dominated by myctophiids, which accounted for ca $71 \%$ of total biomass. The total macroplankton/micronekton abundance at the APF ranged from 0.3 to 29.9 ind. $\mathrm{m}^{-2}$, with an average of 8.7 ind. $\mathrm{m}^{-2}$. Total biomass was 2 to $495 \mathrm{mg}$ dry wt $\mathrm{m}^{-2}$, mean $184 \mathrm{mg} \mathrm{m}^{-2}$ (Fig. 3A, B, Table 2).

In the STC region (Cluster 1) tunicates, siphonophores, euphausiids and chaetognaths were the most abundant groups (Table 3, Fig. 4C). During daytime, about $90 \%$ of total biomass was accounted for by tunicates but, although their abundance increased at night, their contribution decreased to ca $50 \%$ due to the migrations of fish, decapods and euphausiids which made up 26, 10 and $8 \%$ of the total, respectively (Table 3).

Eight species were identified in the tunicate group. Of these, Pyrosoma sp. and Iasis zonaria were the most abundant and frequently encountered (Table 1). Doliolidae, which the hyperiid Phronima sedentaria uses as a hide, were the next most frequent group of tunicates. The dominant chaetognaths were Sagitta gazellae, S. hexaptera and Eukrohnia hamata. Within the siphonophore group, 17 species were identified but the bulk of their abundance was made up of Chelophies appendiculata, Hippopodius hippopus and Lensia 
Table 1. Species composition and frequency of occurrence $(\%)$ of the macrozooplankton/micronekton in the RMT-8 samples collected during Voyages 70 and 72 aboard the SA 'Agulhas' The identification of species in brackets is not conclusive

\begin{tabular}{|c|c|c|c|c|c|c|c|c|}
\hline \multirow{3}{*}{ Taxon } & \multicolumn{5}{|c|}{ Subtropical Convergence region } & \multirow{2}{*}{\multicolumn{3}{|c|}{ Polar Front region }} \\
\hline & \multirow{2}{*}{$\begin{array}{l}\text { Inside } \\
\text { eddy }\end{array}$} & \multirow{2}{*}{$\begin{array}{c}\text { Outside } \\
\text { eddy }\end{array}$} & \multicolumn{3}{|c|}{$36 \mathrm{~h}$ stations } & \multirow[b]{2}{*}{22} & h stati & \\
\hline & & & A & B & C & & 29 & 34 \\
\hline Hydromedusae & & & & & & & & \\
\hline 1. Pegantha margaton & - & - & 25.0 & - & - & & - & - \\
\hline 2. P. triloba & - & - & 12.5 & 14.3 & 16.7 & - & - & - \\
\hline 3. Peganthasp. & 20.0 & - & 12.5 & 14.3 & - & - & - & - \\
\hline 4. Hydromedusae gen. $\mathrm{sp}$. & 20.0 & - & 25.0 & 28.6 & 33.3 & - & - & 40.0 \\
\hline Scyphomedusae & & & & & & & & \\
\hline 5. Periphylla periphylla & - & - & - & 14.3 & - & - & - & - \\
\hline Siphonophora & 1000 & 750 & 875 & 42.9 & 83.3 & - & - & - \\
\hline $\begin{array}{l}\text { 6. Chelophyes appendiculata } \\
\text { 7. Diphyes dispar }\end{array}$ & $\begin{array}{r}100.0 \\
20.0\end{array}$ & t5.0 & $8+.3$ & 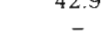 & - & - & - & - \\
\hline 8. Diphyes (antarctica) & - & - & 37.5 & - & - & + & 33.3 & - \\
\hline 9. Muggiaea (atlantica) & 20.0 & - & - & - & - & - & - & - \\
\hline 10. Hippopodius hippopus & 20.0 & - & 62.5 & 14.3 & 16.7 & - & - & - \\
\hline 11. Hippopodius sp. & - & - & 12.5 & - & - & - & - & - \\
\hline 12. Mamus antarcticus & - & - & 12.5 & - & - & - & - & - \\
\hline 13. Marrus sp. & - & 25.0 & - & - & - & - & - & - \\
\hline 14. Eudoxoides spiralis & 40.0 & - & 12.5 & 14.3 & 16.7 & - & - & - \\
\hline 15. Agalma okeni & - & - & 62.5 & - & - & - & - & - \\
\hline 16. Ceratocymba sagittata & - & - & 50.0 & - & - & - & - & - \\
\hline 17. Ceratocymba (dentata) & - & - & 12.5 & - & - & - & - & - \\
\hline 18. Abilopsis (tetragona) & 20.0 & - & 12.5 & - & - & - & - & - \\
\hline 19. Lensia (hostile) & - & 50.0 & - & 100.0 & 100.0 & - & - & - \\
\hline 20. Melophysa (melo) & - & - & - & 14.3 & - & - & - & - \\
\hline 21. Vogtia sp. & 20.0 & - & - & - & - & - & - & - \\
\hline 22. Amphicaryon sp. & - & - & 12.5 & - & - & - & - & - \\
\hline 23. Nectophora (undet.) & 40.0 & 25.0 & 62.5 & 28.6 & 83.3 & + & - & 80.0 \\
\hline Ctenophora & & & & & & & & \\
\hline 24. Pleurobrachia pileus & - & - & 12.5 & 14.3 & 16.7 & - & 33.3 & - \\
\hline Polychaeta & - & 250 & _. & - & - & - & - & - \\
\hline 26. T. carpenteri & - & 25.0 & - & - & - & + & - & - \\
\hline Euphausiacea & & & & & & & & \\
\hline 27. Euphausia similis & - & 50.0 & - & 57.3 & 83.3 & - & - & - \\
\hline 28. E. spinifera & 60.0 & 75.0 & - & 85.8 & 66.7 & - & - & - \\
\hline 29. E. recurva & 20.0 & 25.0 & 62.5 & 42.9 & - & - & - & - \\
\hline 30. E. superba & - & - & - & - & - & + & - & - \\
\hline 31. E. vallentini & - & - & - & - & - & - & 33.3 & 20.0 \\
\hline 32. E. tracantha & - & - & - & - & - & - & 100.0 & 60.0 \\
\hline 33. Euphausia sp. (furcllaa) & - & - & 12.5 & 14.3 & - & - & - & - \\
\hline 34. Nematoscelis megalops & 80.0 & 75.0 & 12.5 & 71.5 & 66.7 & - & - & - \\
\hline 35. Thysanoessa gregaria & - & - & - & 14.3 & - & - & - & - \\
\hline 36. T. macrura & - & - & - & - & - & - & 33.3 & - \\
\hline 37. Thysanoessa spp. & 20.0 & 25.0 & - & 28.6 & - & - & 33.3 & 40.0 \\
\hline 38. Thysanopoda pectinata & 20.0 & - & 25.0 & - & - & - & - & - \\
\hline 39. Stylocheiron maximum & - & - & 25.0 & - & - & - & - & - \\
\hline Amphipoda & & & & & & & & \\
\hline 40. Phronima sedentaria & 20.0 & 25.0 & - & 28.6 & 16.7 & - & - & 40.0 \\
\hline 41. Tetrathyrus forcipatus & - & 25.0 & - & - & - & - & - & - \\
\hline 42. Rhabdosoma whitei & - & - & 12.5 & - & - & - & - & - \\
\hline 43. Streetsia mindanaonis & - & - & 12.5 & - & - & - & - & - \\
\hline 44. Platyscelis ovoides & - & - & 12.5 & - & - & - & - & - \\
\hline 45. Paraphronima crassipes & - & - & - & 14.3 & - & - & - & - \\
\hline 46. Parathemisto gaudichaudii & - & - & - & - & - & - & 66.7 & 100.0 \\
\hline 47. Primno macropa & - & - & 12.5 & 14.3 & - & - & - & 60.0 \\
\hline 48. Vibilia antarctica & - & - & - & - & - & + & 66.7 & 20.0 \\
\hline 49. Vibilia sp. & - & - & 12.5 & 28.6 & - & - & - & - \\
\hline 50. Cyllopus magellanicus & - & - & - & - & - & + & 66.7 & - \\
\hline 51. Lanceola syana & - & - & - & - & - & - & - & 20.0 \\
\hline 52. Gammaridea gen. sp. & - & - & - & 14.3 & - & - & - & - \\
\hline Decapoda & & & & & & & & \\
\hline 53. Hymenodora glaclahs & 20.0 & 25.0 & - & - & 16.7 & - & - & - \\
\hline 54. Systelaspis debills & 40.0 & 25.0 & 37.5 & 14.3 & - & - & - & - \\
\hline 55. Funchalia woodwardi & - & - & 12.5 & - & - & - & - & - \\
\hline 56. Acanthephyra pelagica & 20.0 & - & - & 28.6 & 16.7 & - & - & - \\
\hline 57. Pasiphaea sp. & - & - & - & 14.3 & - & - & - & - \\
\hline 58. Sergestidae gen. sp. 1 & 60.0 & 75.0 & 25.0 & 28.6 & 33.3 & - & - & - \\
\hline 59. Sergestudae gen. sp.2 & 40.0 & 25.0 & 25.0 & - & 16.7 & - & - & - \\
\hline 60. Brachiura (larvae) & 60.0 & - & - & 14.3 & - & - & - & - \\
\hline 61. Phyllosoma (Palinuroidea) & 20.0 & 25.0 & 25.0 & - & - & - & - & - \\
\hline Stomatopoda & & & & & & & & \\
\hline 62. Stomatopoda (larvae) & 20.0 & & 37.5 & 28.6 & 16.7 & - & - & - \\
\hline Pteropoda & & & & & & & & \\
\hline 63. Diacria quadridentata & 20.0 & - & - & - & - & - & - & - \\
\hline 64. Cymbulia sibogae & 40.0 & 25.0 & - & 14.3 & 16.7 & - & - & - \\
\hline
\end{tabular}


Table 1 (continued)

\begin{tabular}{|c|c|c|c|c|c|c|c|c|}
\hline \multirow{3}{*}{ Taxon } & \multicolumn{5}{|c|}{ _ Subtropical Convergence region ____ } & \multicolumn{3}{|c|}{ Polar Front region } \\
\hline & \multirow{2}{*}{$\begin{array}{l}\text { Inside } \\
\text { eddy }\end{array}$} & \multirow{2}{*}{$\begin{array}{l}\text { Outsıde } \\
\text { eddy }\end{array}$} & \multicolumn{3}{|c|}{36 h stations } & \multicolumn{3}{|c|}{$36 \mathrm{~h}$ stations } \\
\hline & & & A. & B & C & 22 & 29 & 34 \\
\hline 65. Cymbulia sp. & 20.0 & - & 25.0 & - & - & - & - & $=$ \\
\hline 66. Cresies virgula & - & - & 12.5 & - & - & - & - & - \\
\hline 67. Limacina retroversa & - & - & 12.5 & - & - & - & - & - \\
\hline 68. L. helicina & - & - & - & 85.8 & 16.7 & - & - & - \\
\hline 69. Clio pyramidata & 20.0 & - & - & - & - & - & - & 20.0 \\
\hline 70. Cliosp. & - & - & 12.5 & - & - & - & - & - \\
\hline 71 Spongiobranchia australis & - & - & - & - & - & - & 33.3 & 80.0 \\
\hline 72. Hyalocylis striata & - & - & 12.5 & - & - & - & - & - \\
\hline Heteropoda & & & & & & & & \\
\hline 73. Pterotrachea sp. & - & 50.0 & 62.5 & 14.3 & - & & - & - \\
\hline $\begin{array}{l}\text { Cephalopoda } \\
74 \text {. Moroteuthis knipovichi }\end{array}$ & - & - & - & - & 16.7 & - & _- & 20.0 \\
\hline 75. Histioteuthis marohista & - & _- & - & - & 16.7 & - & - & - \\
\hline 76. H. atlantica & - & - & - & - & 16.7 & - & - & - \\
\hline 77. Histioteuthidae (larva) & - & - & & 14.3 & - & - & - & - \\
\hline 78. Teuthoidea (larva 1) & - & - & 12.5 & - & - & - & - & - \\
\hline 79. Teuthoidea (larva 2) & - & - & 12.5 & - & - & - & - & - \\
\hline 80. Teuthoidea gen. sp. & - & - & 12.5 & - & - & - & - & - \\
\hline Chaetognatha & & & & & & & & \\
\hline 81. Sagitta gazellae & 40.0 & 75.0 & 37.5 & 85.8 & 100.0 & - & 100.0 & 100.0 \\
\hline 82. 5. hexaptera & 60.0 & - & 25.0 & 14.3 & - & - & - & - \\
\hline 83. S. macrocephala & 40.0 & - & 37.5 & - & - & - & - & - \\
\hline 84. Sagitta sp. & 40.0 & - & 62.5 & 28.6 & - & - & - & - \\
\hline 85. Eukrohnia hamata & 40.0 & - & 62.5 & 42.9 & 33.3 & - & 33.3 & 80.0 \\
\hline 86. Eukrohnia sp. & - & - & 12.5 & - & - & - & - & - \\
\hline Tunicata & & & & & & & & \\
\hline 87. Pyrosoma sp. & 100.0 & 100.0 & 100.0 & 28.6 & 66.7 & - & - & - \\
\hline 88. Doliolidae (tunica) & 100.0 & 25.0 & 25.0 & 42.9 & - & - & - & 60.0 \\
\hline 89. Salpa fusiformis & 20.0 & 25.0 & 50.0 & - & - & - & - & - \\
\hline 90. S. thompsoni & - & 50.0 & - & - & - & + & 100.0 & 40.0 \\
\hline 91. Iasis zonaria & 40.0 & 25.0 & 50.0 & 28.6 & 16.7 & - & - & - \\
\hline 92. Ihlea magalhanica & - & 25.0 & - & 14.3 & 16.7 & - & - & - \\
\hline 93. Thalia orientalis & 20.0 & - & - & - & - & - & - & - \\
\hline 94. Salpidae gen. sp. & - & 25.0 & - & - & - & - & - & - \\
\hline 95. Oikopleura sp. & 20.0 & - & - & - & - & - & - & - \\
\hline Osteichthyes & & & & & & & & \\
\hline $\begin{array}{l}\text { 96. Anguilliformes } \\
\text { (Leptocephalus sp.) }\end{array}$ & 60.0 & - & 12.5 & - & - & - & - & - \\
\hline 97. Electrona subaspera & - & 25.0 & - & - & - & - & - & - \\
\hline 98. Electrona sp. & - & - & - & - & - & + & - & - \\
\hline 99. Diaphus taaningi & 20.0 & 75.0 & 12.5 & 14.3 & 33.3 & - & - & - \\
\hline 100. D. effugens & 20.0 & - & - & - & - & - & - & - \\
\hline 101. D. lutkenı? & - & - & 25.0 & - & - & - & - & - \\
\hline 102. Diaphus sp. & - & - & - & 28.6 & - & - & - & - \\
\hline 103. Protomyctophum bolini & - & - & - & - & - & - & 33.3 & 20.0 \\
\hline 104. P. choriodon & - & - & - & - & - & - & - & 20.0 \\
\hline 105. P. luciferum & - & 25.0 & - & & - & - & 33.3 & - \\
\hline 106. P. normani & - & 25.0 & - & - & - & - & - & - \\
\hline 107. Protomyctophum sp. & - & - & 12.5 & 28.6 & 50.0 & - & 66.7 & 20.0 \\
\hline 108. Krefftichthys anderssoni & - & - & - & - & - & - & 33.3 & - \\
\hline 109. Gymnoscopelus sp. & 20.0 & 25.0 & - & 14.3 & - & - & - & 20.0 \\
\hline 110. Benthosema suborbitale & - & - & 12.5 & - & - & - & - & - \\
\hline 111. Benthosema sp. & - & - & - & - & 16.7 & - & - & - \\
\hline 112. Hygophum hanseni & - & 25.0 & - & - & - & - & - & - \\
\hline 113. Lampadema sp. & - & - & - & - & 16.7 & - & - & - \\
\hline 114. Myctophidae unknown & - & - & 25.0 & - & - & - & - & - \\
\hline 115. Notolepis coatsi & - & - & - & - & - & - & - & 20.0 \\
\hline 116. Argyropelecus hemigymnus & 40.0 & 25.0 & 25.0 & - & - & - & - & - \\
\hline 117. A. aculeatus & - & - & 12.5 & - & - & - & - & - \\
\hline 118. Lobianchia dofleini & - & 50.0 & - & - & - & - & - & - \\
\hline 119. Luciosudis normani & 40.0 & - & - & - & 16.7 & - & - & - \\
\hline 120. Margenthia obtusirostra & - & - & 12.5 & - & - & - & - & - \\
\hline 121. Gonostoma elongatum & 20.0 & - & - & - & - & - & - & - \\
\hline 122. Anoplogaster cornuta & - & - & 12.5 & - & - & - & - & - \\
\hline 123. Indiacanthus atlanticus & - & - & - & 14.3 & - & - & - & - \\
\hline 124. Eustomias sp. & 20.0 & - & - & - & - & - & - & - \\
\hline 125. Sio nordenskjoldii & 20.0 & - & - & - & - & - & - & - \\
\hline 126. Scopelosaunus kreffti? & - & - & - & - & 16.7 & - & - & - \\
\hline 127. Astronesthes sp. & - & - & _- & - & - & - & - & 20.0 \\
\hline 128. Chauliodus sp. & - & 25.0 & - & - & 16.7 & - & - & - \\
\hline 129. Ceratias sp. & - & - & - & 14.3 & - & - & - & - \\
\hline 130. Vincinguerria sp. & 40.0 & - & - & - & 33.3 & - & - & - \\
\hline 131. Bathylagus sp. & 20.0 & - & -. & 14.3 & - & - & - & - \\
\hline 132. Fish eggs & - & - & 62.5 & 28.6 & 16.7 & - & - & - \\
\hline No. of samples & 5 & 4 & 8 & 7 & 6 & 1 & 3 & 5 \\
\hline
\end{tabular}


Table 2. Abundance and biomass of the major groups of the macroplankton/ micronekton in the Antarctic Polar Front region during January-February 1993 (0 to $300 \mathrm{~m}$ )

\begin{tabular}{lcrrrr} 
Group & \multicolumn{2}{c}{ Abundance } & \multicolumn{2}{c}{ Biomass } \\
& $\left(\right.$ ind. $\left.\mathrm{m}^{-2} \pm \mathrm{SD}\right)$ & $\%$ & $\left(\right.$ mg dry wt $\left.\mathrm{m}^{-2} \pm \mathrm{SD}\right)$ & $\%$ \\
\hline Medusae & $0.003 \pm 0.006$ & $<0.1$ & $0.244 \pm 0.485$ & 0.1 \\
Siphonophora & $0.084 \pm 0.119$ & 1.0 & $0.633 \pm 0.784$ & 0.3 \\
Ctenophora & $0.003 \pm 0.008$ & $<0.1$ & $0.467 \pm 1.400$ & 0.3 \\
Polychaeta & $0.006 \pm 0.017$ & 0.1 & $0.033 \pm 0.033$ & $<0.1$ \\
Euphausiacea & $0.894 \pm 1.506$ & 10.2 & $60.660 \pm 155.762$ & 32.9 \\
Amphipoda & $0.250 \pm 0.198$ & 2.9 & $3.111 \pm 3.642$ & 1.7 \\
Pteropoda & $0.017 \pm 0.022$ & 0.2 & $0.389 \pm 0.654$ & 0.2 \\
Cephalopoda & $0.001 \pm 0.004$ & $<0.1$ & $0.178 \pm 0.533$ & 0.1 \\
Chaetognatha & $0.132 \pm 0.092$ & 1.5 & $0.644 \pm 0.787$ & 0.3 \\
Tunicata & $7.293 \pm 10.217$ & 83.5 & $94.622 \pm 136.076$ & 51.3 \\
Osteichthyes & $0.052 \pm 0.076$ & 0.6 & $23.444 \pm 39.984$ & 12.7 \\
& & & & $184 \pm 191$ & 100.0 \\
Total & $8.7 \pm 10.6$ & 100.0 & & \\
\hline
\end{tabular}

\section{Distribution}

The spatial distribution of the macroplankton/micronekton at the APF was characterized by a sharp increase in the abundance of Salpa thompsoni (Fig. 3C) at the centre of the APF (Stn 29), compared to the stations located immediately north and south of the front, where abundance levels of tunicates were similar and relatively low (Fig. 3C). However, total biomass decreased regularly across the APF, moving from the south to the north of the front (Fig. 5A). This was due mainly to the disappearance of Euphausia superba, which constituted the bulk of the macroplankton at Stn 22 (Fig. 3C), south of the surface expression of the APF

(hostile). Other common macroplankton were euphausiids, mostly Nematoscelis megalops, E. spinifera, E. recurva and E. similis, and decapod shrimps, mainly Systelaspis debilis and Sergestidae. Myctophiids consistently dominated the fish community at both fronts.

Total macroplankton abundance in the STC region varied from 0.2 to 6.9 ind. $\mathrm{m}^{-2}$ (average 1.6 ind. $\mathrm{m}^{-2}$ ) during the daytime and from 1.3 to 10.6 ind. $\mathrm{m}^{-2}$ (average 4.2 ind. $\mathrm{m}^{-2}$ ), during the nighttime (Table 3, Fig. 4).

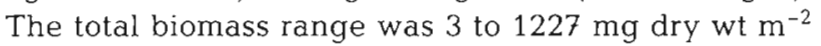
(mean $101 \mathrm{mg} \mathrm{m}^{-2}$ ) and 26 to $755 \mathrm{mg} \mathrm{m}^{-2}$ (mean $234 \mathrm{mg} \mathrm{m}^{-2}$ ) during the day and night, respectively (Table 3, Fig. 4A, B).
Sharp changes in abundance and biomass were also found along the transect crossing the STC (Fig. 5B). Total abundance decreased dramatically from north to south of the front and correlated positively with the drop in temperature but negatively with the increase in chlorophyll a concentration (Fig. 5B). The highest peaks in total biomass were observed in the centre of the STC and immediately south of it. No significant differences ( $t$-test, $p>0.1$ ) were observed in the levels of biomass and abundance between stations inside and outside the warm-core eddy (Fig. 4B). However, community structure within the eddy was different from that of surrounding waters. In particular, meroplank-

Table 3. Abundance and biomass of the major groups of the macroplankton/micronekton in the Subtropical Convergence region during June-July 1993 (0 to $300 \mathrm{~m}$ )

\begin{tabular}{|c|c|c|c|c|c|c|c|c|}
\hline \multirow[t]{3}{*}{ Group } & \multicolumn{4}{|c|}{ Daytime } & \multicolumn{4}{|c|}{ - Nighttime } \\
\hline & \multicolumn{2}{|c|}{ Abundance } & \multicolumn{2}{|l|}{ Biomass } & \multicolumn{2}{|c|}{ Abundance } & \multicolumn{2}{|l|}{ Biomass } \\
\hline & (ind. $\mathrm{m}^{-2} \pm \mathrm{SD}$ ) & $\%$ & $\left(m g\right.$ dry wt $m^{-2} \pm S D$ & $\%$ & (ind. $\mathrm{m}^{-2} \pm \mathrm{SD}$ ) & $\%$ & (mg dry wt m-2 $\pm \mathrm{SD}$ & D) $\%$ \\
\hline Medusae & $0.036 \pm 0.055$ & 2.2 & $3.627 \pm 0.269$ & 3.6 & $0.051 \pm 0.078$ & 1.2 & $2.007 \pm 4.040$ & 0.9 \\
\hline Siphonophora & $0.409 \pm 0.378$ & 24.5 & $1.386 \pm 1.582$ & 1.4 & $1.095 \pm 1.282$ & 26.3 & $3.487 \pm 4.312$ & 1.5 \\
\hline Ctenophora & $0.008 \pm 0.025$ & 0.5 & $0.352 \pm 0.933$ & 0.3 & $0.002 \pm 0.008$ & 0.1 & $0.080 \pm 0.309$ & $<0.1$ \\
\hline Polychaeta & - & - & - & - & $0.002 \pm 0.008$ & 0.1 & $0.003 \pm 0.010$ & $<0.1$ \\
\hline Euphausiacea & $0.113 \pm 0.129$ & 6.9 & $0.663 \pm 0.949$ & 0.7 & $1.170 \pm 1.042$ & 28.1 & $18.960 \pm 24.466$ & 8.1 \\
\hline Amphipoda & $0.008 \pm 0.015$ & 0.5 & $0.055 \pm 0.140$ & $<0.1$ & $0.032 \pm 0.053$ & 0.8 & $0.703 \pm 2.302$ & 0.3 \\
\hline Decapoda & $0.012 \pm 0.026$ & 0.7 & $0.647 \pm 0.149$ & 0.6 & $0.216 \pm 0.179$ & 5.2 & $22.127 \pm 21.448$ & 9.5 \\
\hline Stomatopoda & $0.027 \pm 0.044$ & 1.6 & $0.493 \pm 1.141$ & 0.5 & $0.009 \pm 0.019$ & 0.2 & $0.093 \pm 0.234$ & $<0.1$ \\
\hline Pteropoda & $0.028 \pm 0.034$ & 1.7 & $0.204 \pm 0.465$ & 0.2 & $0.042 \pm 0.071$ & 1.0 & $1.137 \pm 2.389$ & 0.5 \\
\hline Heteropoda & $0.006 \pm 0.018$ & 0.4 & $0.100 \pm 0.314$ & 0.1 & $0.018 \pm 0.028$ & 0.4 & $2.313 \pm 6.882$ & 1.0 \\
\hline Cephalopoda & $0.009 \pm 0.023$ & 0.5 & $0.287 \pm 0.759$ & 0.3 & $0.012 \pm 0.026$ & 0.3 & $7.887 \pm 25.626$ & 3.4 \\
\hline Chaetognatha & $0.211 \pm 0.142$ & 12.8 & $0.358 \pm 0.390$ & 0.4 & $0.172 \pm 0.164$ & 4.1 & $0.316 \pm 0.453$ & 0.1 \\
\hline Tunicata & $0.698 \pm 1.535$ & 42.5 & $90.000 \pm 313.45$ & 89.5 & $1.188 \pm 2.257$ & 28.5 & $114.047 \pm 175.64$ & 48.8 \\
\hline Osteichthyes & $0.079 \pm 0.097$ & 4.8 & $2.433 \pm 2.975$ & 2.4 & $0.153 \pm 0.088$ & 3.7 & $60.460 \pm 76.613$ & 25.9 \\
\hline Total & $1.6 \pm 1.7$ & 100.0 & $101 \pm 312$ & 100.0 & $4.2 \pm 3.2$ & 100.0 & $234 \pm 224$ & 100.0 \\
\hline
\end{tabular}



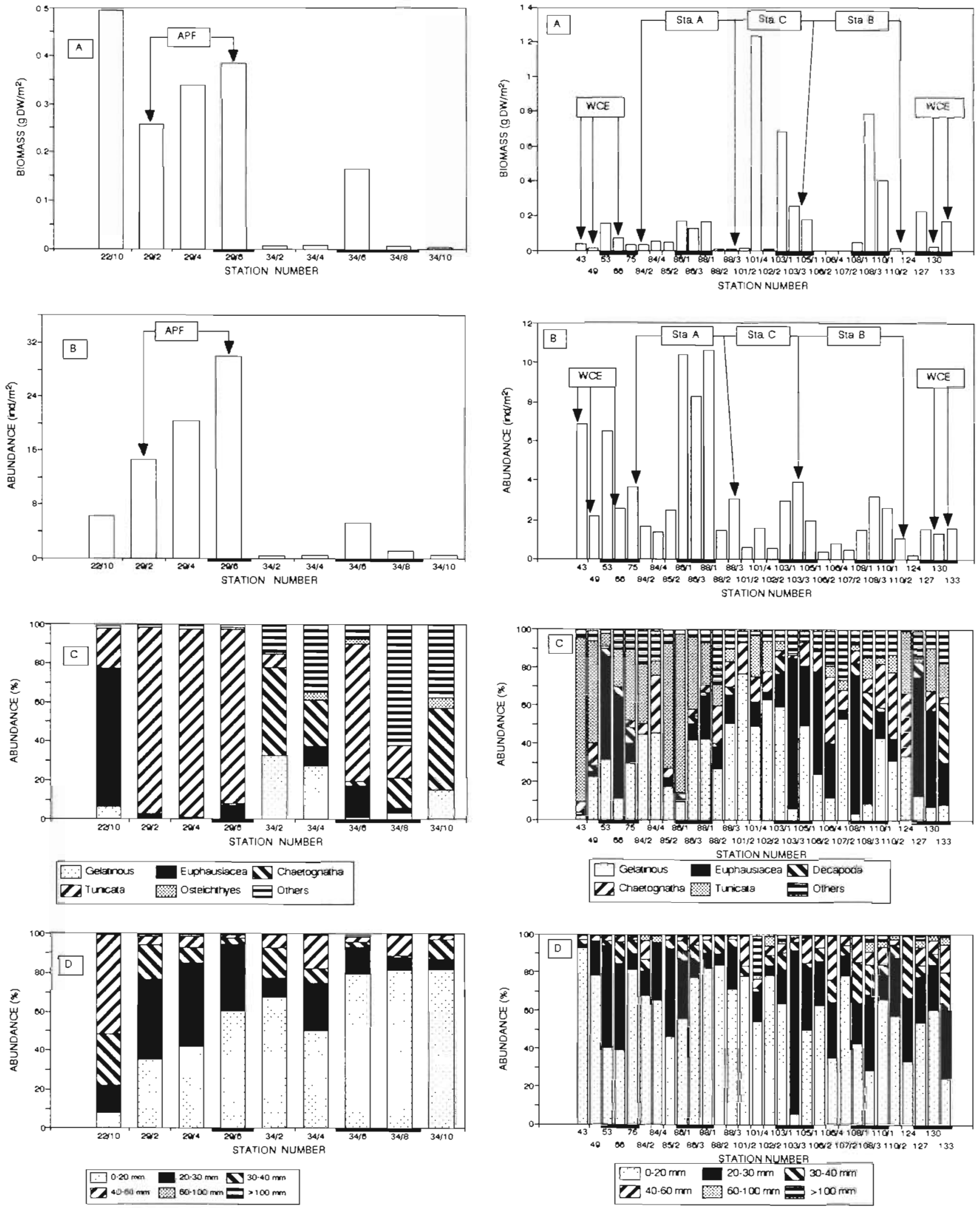

Fig. 3. Total biomass (A), abundance (B), percentage taxonomic (C) and size (D) composition of the macroplankton/ micronekton community of the APF zone during JanuaryFebruary 1993. Period of darkness is indicated by thickening of the horizontal axis

Fig. 4. Total biomass (A), abundance (B), percentage taxonomic (C) and size (D) composition of the macroplankton/ micronekton community of the STC zone during June-July 1993. Period of darkness is indicated by thickening of the horizontal axis 

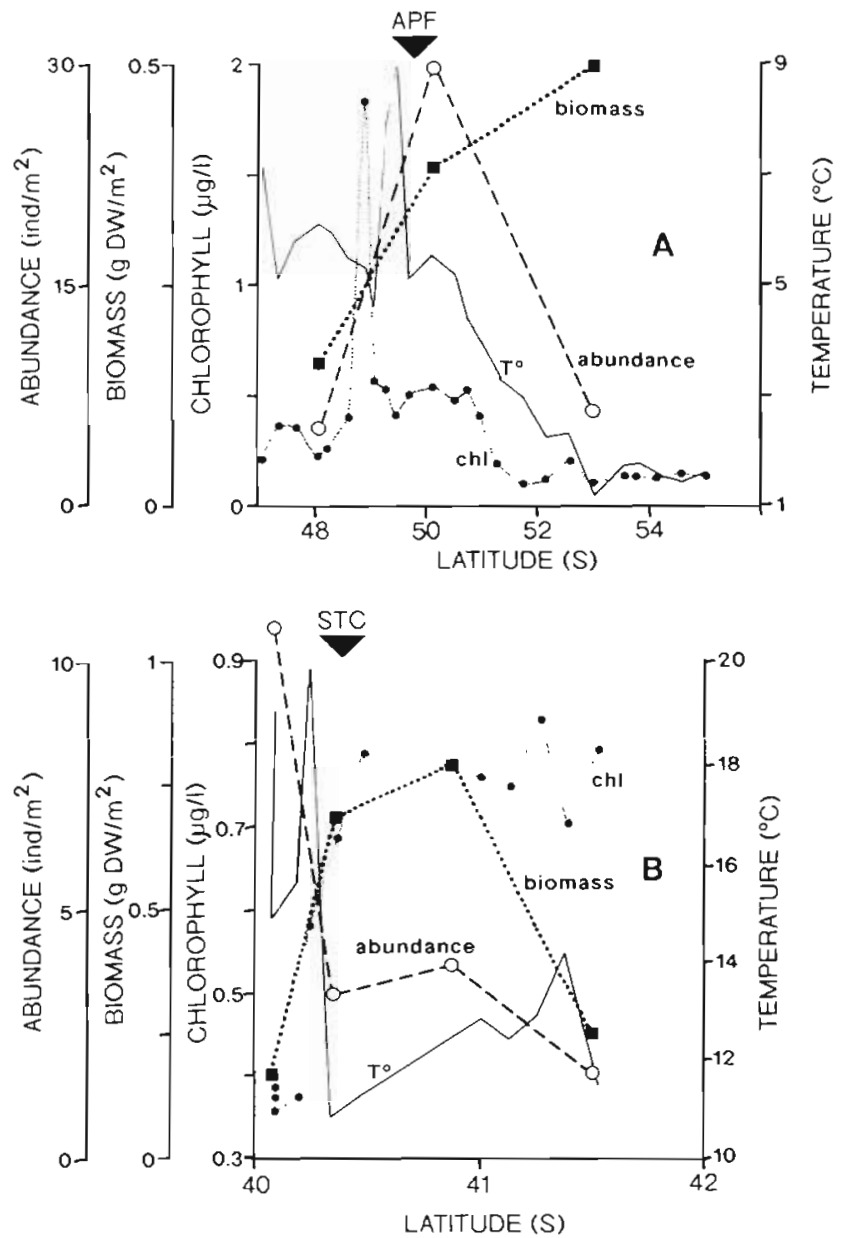

Fig. 5. Changes in surface chlorophyll a concentration (chl), surface temperature $\left(\mathrm{T}^{\circ}\right)$, macroplankton/micronekton abundance and biomass across (A) the APF and (B) the STC zones

tonic larvae of subtropical origin (larvae of Stomatopoda, Brachiura and Phyllosoma) were common inside the eddy but completely absent outside (Table 1).

\section{Size composition}

Within the APF zone 5 to $35 \mathrm{~mm}$ tunicates made up most of the local stock. There was also a minor peak in abundance of animals in the size range of 40 to $60 \mathrm{~mm}$ largely due to high densities of Euphasuia superba (Fig. 6A, B). The size distribution of total biomass exhibited 2 modal peaks. The first in the 20 to $30 \mathrm{~mm}$ range was due to tunicates and euphausiids and the second, 40 to $60 \mathrm{~mm}$, was due mostly to euphausiids. The 60 to $80 \mathrm{~mm}$ size group was dominated by myctophiid fish, large tunicates and chaetognaths (Fig. 6C, D). Stn 22 (Cluster 3) was dominated by euphausiids with length of 40 to $60 \mathrm{~mm}$ which accounted for about $80 \%$ of the total abundance (Fig. 3C, D). On the other hand, Stns 29 \& 34 (Cluster 2) were dominated by smaller organisms, of lengths ranging from 5 to $30 \mathrm{~mm}$ (Figs. 3D \& 6A).

In the STC region, the 0 to $20 \mathrm{~mm}$ size fraction accounted for most of the daytime abundance. A significant increase in the proportion of 20 to $40 \mathrm{~mm}$ animals (up to $90 \%$ of total abundance at Stn 103/3; Fig. 4D) was observed in nighttime samples. The distribution of size versus abundance shows a predominance of taxonomic groups of small size (5 to $30 \mathrm{~mm}$ ): siphonophores, tunicates and euphausiids. The contribution of chaetognaths was highest in the 40 to $50 \mathrm{~mm}$ size range. The relative proportion of fishes increased substantially above the length of $60 \mathrm{~mm}$ (Fig. 7A, B). The tail of the size distribution diagram is due to large Pyrosoma sp. (length up to 100 to $300 \mathrm{~mm}$ ) and deep water fish of the Stomiidae. The distribution of size versus biomass exhibits 3 peaks and is skewed to the right (Fig. $7 \mathrm{C}$ ). The first peak $(20$ to $30 \mathrm{~mm}$ ) is mostly due to euphausiids (Euphausia spinifera and E. similis), the second ( 40 to $80 \mathrm{~mm}$ ) to decapods and chaetognaths, while the third peak ( 80 to $100 \mathrm{~mm}$ ) is composed of a mixture of myctophiid fishes and decapods. As for the abundance diagram, about $80 \%$ of the total biomass in the tail size classes is due to large colonial Pyrosoma sp. (Fig. 7C, D).

\section{Vertical migrations}

The main taxonomic groups of macroplankton and micronekton (i.e. euphausiids, decapods and fish) showed a clear pattern of vertical migration in both frontal regions (Figs. $3 \& 4$ ), with significant differences between average abundance and biomass in daytime and nighttime samples ( $t$-test, $\mathrm{p}<0.001)$. Total macroplankton/micronekton abundance was also significantly different ( $t$-test, $p<0.05$ ) between daytime and nighttime samples. However, biomass differences were not significant ( $t$-test, $p>0.1$ ). Hydroacoustic data show that macroplankton/micronekton backscattering increased in nearsurface waters $(0$ to $100 \mathrm{~m}$ ) at night at all stations in both regions. During the day, however, maximum backscattering intensity was found between 100 and $250 \mathrm{~m}$, and often even deeper (Fig. 8).

\section{DISCUSSION}

Recent investigations have shown that frontal regions contribute substantially to the total productivity of the Southern Ocean (Allanson et al. 1981, Lutjeharms et al. 1985, El-Sayed 1988, Laubscher et al. 1993). Enhancements in the activity and abundance of 

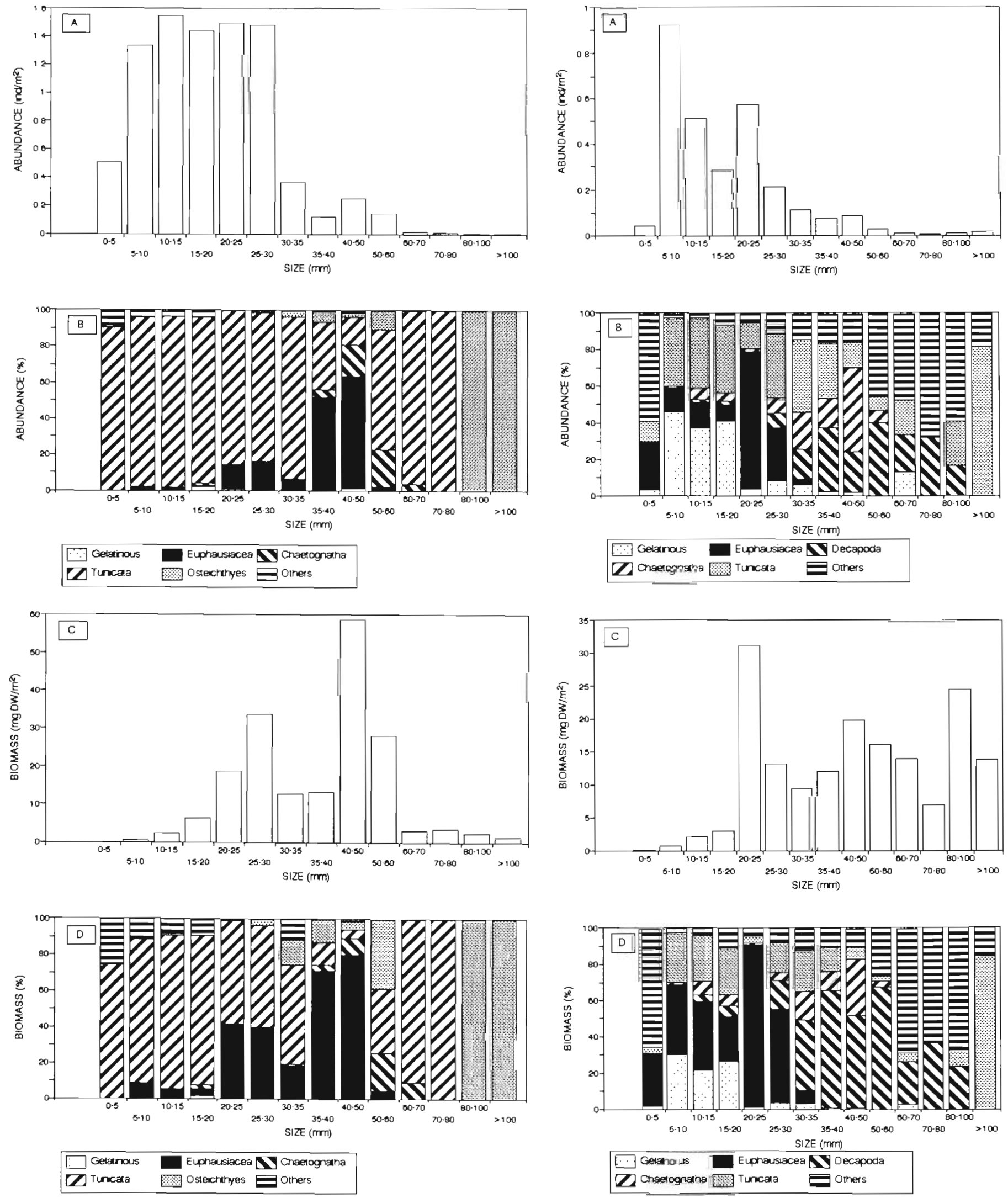

Fig. 6. Total and percentage distribution of macroplankton/ micronekton abundance $(A \& B)$ and biomass ( $C \& D)$ versus size at the APF zone during January-February 1993

Fig. 7. Total and percentage distribution of macroplankton/ micronekton abundance (A \& B) and biomass (C \& D) versus size at the STC zone during June-July 1993 

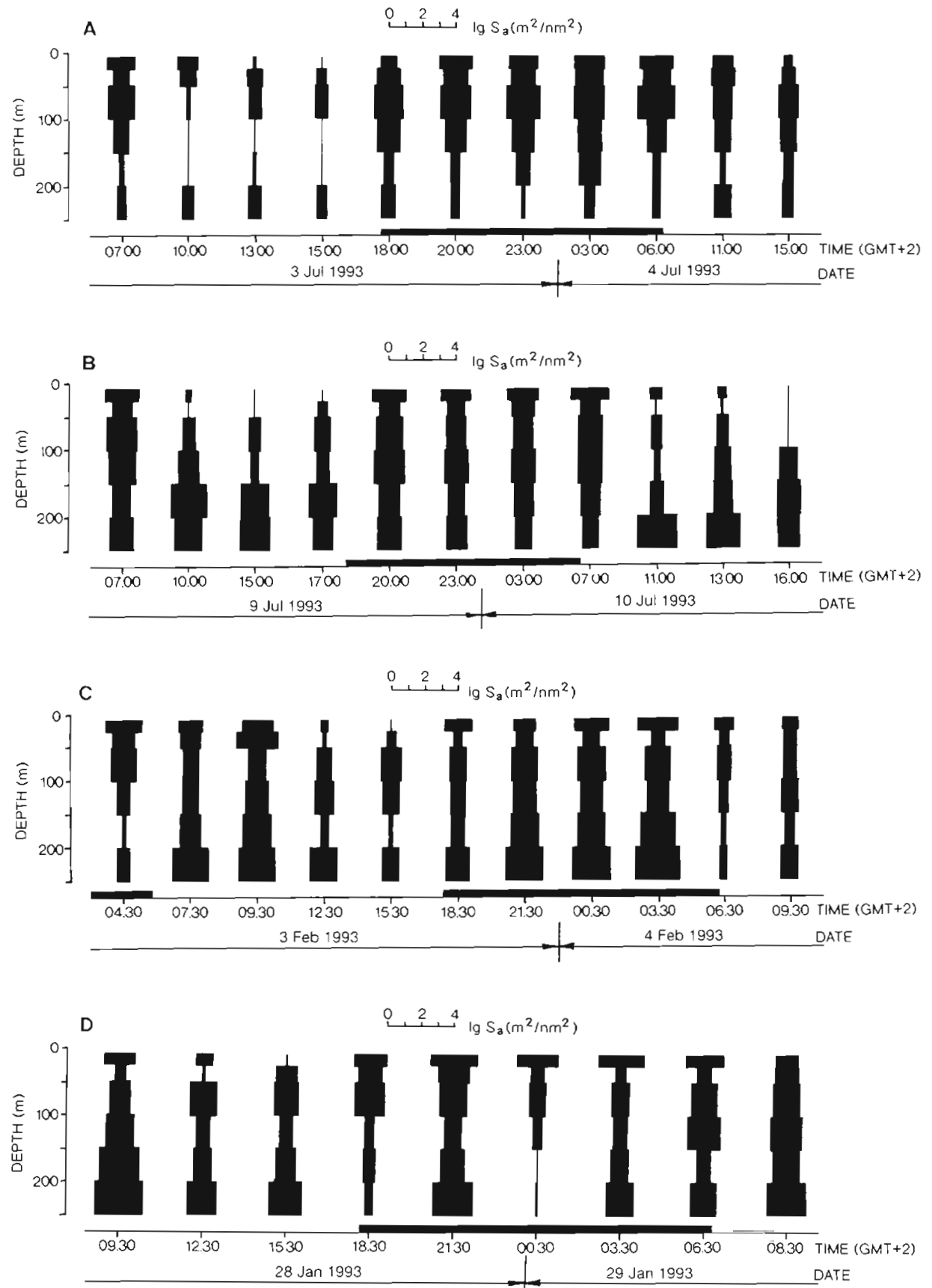

Fig. 8. Vertical distribution of planktonic backscattering intensity $(120 \mathrm{kHz})$ at the STC (A \& B) and the APF (C \& D) zones. A: STC Stn A; B: STC Stn B; C: APF Stn 34; D: APF Stn 22. Period of darkness is indicated by thickening of the horizontal axis

birds and mammals have often been observed in the proximity of Southern Ocean fronts in conjunction with an increase in primary production (Shuntov et al. 1982, Batytskaja \& Shurunov 1983, Abrams 1985, Cockcroft et al. 1990). The macroplankton and the micronekton are the intermediaries which channel primary and secondary productivity to the highest trophic levels. These components occupy, therefore, a key position in the Southern Ocean carbon cycle and reliable estimates of the efficiency of the biological pump can be obtained only after their community structure is identi- fied and their stocks and consumption rates are correctly assessed.

The species richness (115) observed in the STC zone during the winter cruise was much higher than the value of 56 previously recorded in the Gough Island region (Miller 1982b), which lies just south of the STC. In our study the number of species was actually closer to the values usually observed at higher latitudes, in the vicinity of the Antarctic continent, where species richness varies between ca 60 and 140, depending on the sector considered (Mackintosh 1934, Hardy \& Gun- 
ther 1935, Dolzhenkov 1975, Piatkowski 1987, Pakhomov 1991, Hosie 1993). A total of 32 species of macroplankton/micronekton were found in the APF zone during the summer cruise. Species richness at the APF is well within the range reported in the literature for this region. Specifically, 41, 47 and 30 species were reported for the areas around the Prince Edward Archipelago (Miller 1982a, Boden \& Parker 1986), the Kerguelen Archipelago (Koubbi 1993, Pakhomov 1993a, Piatkowski 1993) and the open ocean at $57^{\circ} \mathrm{S}$ in the Atlantic sector (Pakhomov 1991), respectively. Most of the species found during both surveys are common and exhibit circumpolar distribution in the Southern Ocean (Baker 1954).

The STC and the APF have some environmental features in common and, in particular, they represent the 2 main sites where dense, cold surface waters sink under warmer, less dense waters (Deacon 1982, Lutjeharms 1985). They are also regarded as strong biogeographical boundaries, demarcating the subtropical, Subantarctic and Antarctic pelagic realms of the Southern Ocean (Rustad 1930, Naumov et al. 1962, Dolzhenkov 1982). The taxonomic analysis of our samples confirms the marked differences between the macroplankton/micronekton communities of the STC and the APF regions. All stations from the STC survey were included in the first group of the cluster analysis (Fig. 2). The highest species similarity was found between stations situated in the centre of the STC and immediately south of it. On the other hand, the lowest coefficient of similarity was obtained between the station located to the north of the STC and outside the warm-core eddy. This is a well-known effect due to a drastic reduction in the number of subtropical species observed at the edge of warm-core eddies (Angel \& Fasham 1983, Davis \& Wiebe 1985). Thus, although the STC is a strong biogeographical front, eddy shedding results in many tropical and subtropical species penetrating through the STC in the Subantarctic region (Lutjeharms 1988). For example, the subtropical hyperiid Phronima sedentaria, which is usually not encountered south of the STC (Vinogradov et al. 1982), was found during this survey, as far south as the northern border of the APF. However it is likely to be a zone where these species are not able to reproduce successfully.

The second cluster included mainly euphausiids and salps found north of the APF. The euphausiid Euphausia triacantha is a common species in the southern part of the Subantarctic zone (Lomakina 1964) and is most concentrated at the APF. On the other hand, the APF zone represents the southern boundary of distribution of the subantarctic krill E. vallentini (Lomakina 1964). Indeed, both of these euphausiids were observed in the middle of the APF and immediately north of it. The salp Salpa thompsoni was also found in abundance in our samples from the APF. This species is widely distributed in the Subantarctic and Antarctic zones (Foxton 1966) and appears to occur as far south as the pack ice (Piatkowski 1987, Lancraft et al. 1991, Siegel et al. 1992). During this survey, the abundance of $S$. thompsoni decreased dramatically south of the APF, with maximum concentrations coinciding with the increase in surface temperature, chlorophyll biomass and primary production (R. Laubscher unpubl.) observed in the middle of the APF.

The third grouping of the cluster analysis was dominated by the Antarctic krill Euphausia superba which exhibits a distribution range limited to the north by the surface expression of the APF (Marr 1962, Lomakina 1964, Mackintosh 1973, Grachev 1991). It was found only at Stn 22, immediately to the south of the APF. Also, the macroplankton composition at this station was very similar to the typical oceanic community described for the Weddell Sea and the Antarctic Peninsula region (Piatkowski 1987, Siegel \& Piatkowski 1990, Boysen-Ennen et al. 1991). Our results on the taxonomic composition and distribution of the macroplankton/micronekton support, therefore, the recent conclusions of Lancraft et al. (1991) and Siegel et al. (1992) that E. superba is most abundant in the Scotia Weddell Seas and in the proximity of the APF, while Salpa thompsoni is most abundant to the north, in open ocean waters. Salps, with copepods, also dominate the total zooplankton stock of the Subantarctic zone and Polar Frontal Zone (PFZ) (Foxton 1966, Maruyama et al. 1982, Voronina 1984, Grachev 1991).

Although the APF and the STC zones were investigated in different seasons, the mean abundance and biomass of macroplankton/micronekton were very similar in the 2 regions. Biomass levels recorded at the STC and APF during this study are comparable to the mean values usually found in the open Subantarctic and PFZ of the Southern Ocean (Tables 2, 3 \& 4). Within the 2 fronts, maximum biomass levels were higher than in the interfrontal zones. However, these levels were lower than those reported for the same fronts in other studies (Table 4). Also, south of the APF biomass levels were higher than those generally observed in subantarctic waters, with the exception of island shelves where levels are comparable to those found at the oceanic fronts (Table 4).

The STC region exhibited considerable fluctuations in the abundance and biomass levels of macroplankton/micronekton which appeared to covary with the spatial distribution of the phytoplankton stock in the area. Within the A.PF region, only total abundance matched the distribution of chlorophyll and primary production, while biomass increased throughout the APF zone, from north to south. 
Table 4. Mean macrozooplankton biomass in different areas of the Southern Ocean

\begin{tabular}{|c|c|c|}
\hline Source & Region, season, layer & Mean biomass ( $g$ dry wt $\mathrm{m}^{-2}$ ) \\
\hline \multirow[b]{2}{*}{ Hopkins (1971) } & Subantarctic, open waters & \\
\hline & $\begin{array}{l}\text { Subantarctic, annual, } 0-1000 \mathrm{~m} \\
\text { Antarctic Convergence, annual, } 0-1000 \mathrm{~m}\end{array}$ & $\begin{array}{l}0.805^{\circ} \\
0.885^{\circ}\end{array}$ \\
\hline Dolzhenkov (1975) & Pacific Ocean, summer, $0-100 \mathrm{~m}$ & 0.057 \\
\hline Maruyama et al. (1982) & Pacific Ocean, Subantarctic front, summer, $0-300 \mathrm{~m}$ & 1.304 \\
\hline Muravjova (1982) & $\begin{array}{l}\text { Pacific Ocean, mountain range Gerakl, winter, } 0-100 \mathrm{~m} \\
\text { Pacific Ocean, mountain range Gerakl, summer, } 0-100 \mathrm{~m}\end{array}$ & $\begin{array}{l}0.012 \\
0.024\end{array}$ \\
\hline \multirow[t]{2}{*}{ Barchatov (1985) } & $\begin{array}{l}\text { Pacific Ocean, summer, } 0-200 \mathrm{~m} \\
\text { Subtropical Convergence, summer, } 0-200 \mathrm{~m}\end{array}$ & $\begin{array}{l}0.131 \\
4.4(\max )\end{array}$ \\
\hline & Subantarctic, around islands & \\
\hline Miller (1982a) & Prince Edward Islands, winter, $0-50 \mathrm{~m}$ & 0.007 \\
\hline Miller (1982b) & Gough lsland, early summer, $0-50 \mathrm{~m}$ & 0.013 \\
\hline Perissinotto \& McQuaid (1992) & Prince Edward Islands, shelf, summer, $0-300 \mathrm{~m}$ & $2.62-2.86$ \\
\hline Pakhomov (1993a) & Kerguelen Archipelago, summer $1988,0-200 \mathrm{~m}$ & 0.498 \\
\hline \multirow[t]{2}{*}{ Semelkina (1993) } & $\begin{array}{r}\text { Kerguelen Archipelago, autumn } 1987,0-500 \mathrm{~m} \\
\text { winter } 1987,0-500 \mathrm{~m} \\
\text { summer } 1988,0-500 \mathrm{~m}\end{array}$ & $\begin{array}{l}1.155^{b} \\
0.156^{b} \\
0.558^{b}\end{array}$ \\
\hline & Antarctic, south of the Antarctic Polar Front & \\
\hline Hopkins (1987) & McMurdo Sound, summer, $0-800 \mathrm{~m}$ & $0.21-0.8$ \\
\hline Hopkins et al. (1989) & Scotia Sea (AMERIEZ), ice edge, winter, $0-1000 \mathrm{~m}$ & 0.245 \\
\hline Lancraft et al. (1989) & Scotia Sea (AMERIEZ), open water, winter, 0-1000 m & $2.4-3.1$ \\
\hline Boysen-Ennen et al. (1991) & Weddell Sea, summer, $0-300 \mathrm{~m}$ & $1.2-3.4$ \\
\hline Lancraft et al. (1991) & Scotia Sea (AMERIEZ), open water, winter, 0-1000 m & 2.978 \\
\hline Pakhomov (1991) & $57^{\circ} 00^{\prime} \mathrm{S}, 20^{\circ} 00^{\prime} \mathrm{W}$, summer, $0-150(200) \mathrm{m}$ & $0.023-1.32$ \\
\hline Siegel et al. (1992) & Scotia Sea (EPOS), winter, $0-60 \mathrm{~m}$ & $0.076-0.435$ \\
\hline Pakhomov (1993b) & $\begin{array}{l}\text { Indian Ocean, Ob \& Lena banks, summer, } 0-200 \mathrm{~m} \\
\text { Indian Ocean, Ob \& Lena banks, spring, 0-500 m }\end{array}$ & $\begin{array}{l}0.442 \\
0.170^{\circ}\end{array}$ \\
\hline \multicolumn{3}{|c|}{$\begin{array}{l}\text { b From vertical tows (euphausiids \& amphipods only) } \\
\text { c From vertical tows (Salpa thompsoni only) }\end{array}$} \\
\hline
\end{tabular}

Within the Atlantic sector of the Southern Ocean, immediately south of the APF region, the macroplankton/micronekton biomass is generally dominated by the large stock of Euphausia superba (Marr 1962, Mackintosh 1973). During our survey, no RMT- 8 tows were made south of $\operatorname{Stn} 22$, at the southern edge of the APF. However, according to the results of Bongo net tows, which will be presented elsewhere, the biomass of Euphausia superba decreased dramatically south of this station. Thus, it is likely that the total macroplankton/micronekton biomass followed the same pattern, showing enhanced levels only in close proximity to the APF and decreasing sharply south of it.

It must be stressed that while the seasonal influence on the productivity of the region of the APF is very marked (Voronina 1984, El-Sayed 1988, Comiso et al.
1993, Semelkina 1993), the STC is relatively uniform throughout the year. At the primary trophic levels in particular, the area of the STC exhibits little variation in the phytoplankton stock in the different seasons (Allanson et al. 1985, Comiso et al. 1993, Weeks \& Shillington 1994). Thus, while macroplankton/micronekton assemblages at the APF are expected to differ substantially, both qualitatively and quantitatively, between winter and summer, it is likely that they change little at the STC during the annual cycle.

The most abundant macroplankton/micronekton feeding groups in both frontal regions were herbivorous tunicates and euphausiids. In the STC region, carnivorous siphonophores and chaetognaths constituted the second largest proportion. In terms of biomass, tunicates, euphausiids, decapods (STC only) and fish 
dominated the stock. The first 3 groups are generally regarded as dominant throughout the Southern Ocean (Maruyama et al. 1982, Miller 1982a, b, Piatkowski 1987, Pakhomov 1989, Lancraft et al. 1991, Siegel et al. 1992). Fishes, however, are mostly represented by the family Myctophidae and are most densely concentrated between the STC and the APF, particularly in the area of the Subantarctic Front (Chindonova 1987 , Zemsky 1987, Maslennikov et al. 1990). In this zone, mesopelagic myctophiids may reach biomass levels of up to 10 to $11.3 \mathrm{~g}$ dry wt $\mathrm{m}^{-2}$, and estimates of mean biomass are in the range of 1.3 to $2.5 \mathrm{~g}$ dry wt $\mathrm{m}^{-2}$ (Linkowski 1983, Zemsky 1987). Similar values, ca 0.7 to $11.0 \mathrm{~g}$ dry $w \mathrm{t} \mathrm{m}^{-2}$, have also been observed in the marginal ice zone (Lancraft et al. 1989). Our estimates of myctophiid biomass are significantly lower than these values. In the STC region, average nighttime biomass was $0.06 \mathrm{~g}$ dry wt $\mathrm{m}^{-2}$ ( $\max 0.302 \mathrm{~g} \mathrm{~m}^{-2}$ ), while at the APF this reached a maximum of $0.117 \mathrm{~g} \mathrm{~m}^{-2}$. This discrepancy in the biomass levels of myctophiids between our study and others is probably due to the fact that only the 0 to $300 \mathrm{~m}$ upper layer was sampled during our survey. Previous estimations have been made using data from much deeper sampling depths, and often from areas with extremely high aggregations of mesopelagic fish. Our data on myctophiid biomass are, therefore, only partly comparable with estimates from other studies.

The macroplankton/micronekton size composition was also similar for both the APF and the STC regions. Both fronts were dominated by mid-size opportunist filter-feeders, such as tunicates and euphausiids, probably as a result of the high primary productivity rates of these regions. The carnivore component was represented by small siphonophores and larger chaetognaths, decapods and myctophiids (vertical migrators).

Grachev (1991) has recently shown that the general size structure of the Southern Ocean zooplankton community changes dramatically moving along a northsouth transect. Particularly, in the APF region the proportion of macroplankton/micronekton decreases sharply, while the total biomass does not change significantly due to a parallel increase in mesoplankton biomass. Boysen-Ennen et al. (1991) have shown that the macroplankton community of the Weddell Sea is dominated by 5 to $10 \mathrm{~mm}$ sized salps and 20 to $40 \mathrm{~mm}$ euphausiids. Our data are consistent with these results and it is, therefore, possible that the same size classes dominate through much of the Southern Ocean.

Most of the groups of macroplankton/micronekton of the APF and the STC undergo diurnal vertical migrations. This feature may play an important role by effectively removing a major portion of the photosynthetically fixed $\mathrm{CO}_{2}$ from surface to deep water through nighttime grazing at the surface and the production of faecal pellets below the euphotic zone during daytime. On the other hand, micronektonic fishes, decapods, cephalopods and euphausiids are effectively consumed by marine birds and mammals (Ainley et al. 1988, Huntley et al. 1991, Hopkins et al. 1993). Therefore, the APF and especially the STC region may promote, through their high macroplankton/micronekton biomass, an increase in the abundance of the top predators and, consequently expand the carbon flow through the trophic pyramid. This would lead to increased respiratory losses of $\mathrm{CO}_{2}$ to the atmosphere, thereby diminishing the efficiency of the biological pump (Huntley et al. 1991).

Acknowledgements. We are very grateful to the South African Department of Environment Affairs and Rhodes University for providing funding and facilities for this study. We also thank the officers and crew of the SA 'Agulhas' and our colleagues from the University of Cape Town for their help at sea. Special thanks go to O. Gon (J. L. B. Smith Institute of Ichthyology, Grahamstown) for the identification of the fish collected during the survey.

\section{LITERATURE CITED}

Abrams, R. W. (1985). Energy and food requirements of pelagic aerial seabirds in different regions of the African sector of the Southern Ocean. In: Siegfried, W. R., Condy, P. R., Laws, R. M. (eds.) Antarctic nutrient cycles and food webs. Springer-Verlag, Berlin, p. 466-472

Ainley, D. G., Fraser, W. R., Daly K. L. (1988). Effects of pack ice on the composition of micronektonic communities in the Weddell Sea. In: Sahrhage, D. (ed.) Antarctic Ocean and resources variability. Springer-Verlag, Berlin, p. $140-146$

Allanson, B. R., Boden, B., Parker, L., Duncombe Rae, C. (1985). A contribution to the oceanology of the Prince Edward Islands. In: Siegfried, W. R., Condy, P. R., Laws, R. M. (eds.) Antarctic nutrient cycles and food webs. Springer-Verlag, Berlin, p. 38-45

Allanson, B. R., Hart, R. C. Lutjeharms, J. R. E. (1981). Observations on the nutrients, chlorophyll and primary production of the Southern Ocean south of Africa. S. Afr. J. Antarct. Res. 10/11: 3-14

Angel, M. M., Fasham, M. J. R. (1983). Eddies and biological processes. In: Robinson, A. R. (ed.) Eddies in marine science. Springer-Verlag, Berlin, p. 492-524

Baker, A. de C. (1954). The circumpolar continuity of Antarctic plankton species. Discovery Rep. 26: 201-218

Baker, A de C., Clarke, M. R., Harris, M. J. (1973). The N.I.O. combination net (RMT $1+8$ ) and further developments of rectangular midwater trawls. J. mar. biol. Ass. U.K. 53: $167-184$

Barchatov, V. A. (1985). Quantity distribution of macroplankton in the south part of the Pacific Ocean during summer 1984-85. Report of 34 cruise R/V 'Dmitry Mendeleev', Vol. 3. IO RAN (Shirshov Institute Oceanology Russian Academy Science) Press, Moscow, p. 75-89 (in Russian)

Batytskaja, L. V., Shurunov, N. A. (1983). Distribution of seabirds in the Southern Ocean with the connection of the distribution of water masses during austral summer. J. Zool. 62: 755-760 (in Russian) 
Boden, B. P., Patker, L. D. (1986). The plankton of the Prince Edward Islands. Polar Biol. 5: 81-93

Boysen-Ennen, E., Hagen, W., Hubold, G., Piatkowski, U (1991). Zooplankton biomass in the ice-covered Weddell Sea, Antarctica. Mar. Biol. 111: 227-235

Chapman, P., Duncombe Rae, C. M., Allanson, B. R. (1987) Nutrients, chlorophyll and oxygen relationships in the surface layers at the Agulhas Retroflection. Deep Sea Res. 34 $1399-1416$

Chindonova, Yu. G. (1987). Quantity distribution of mesopelagic fishes in the Atlantic sector of the Southern Ocean. In: Novikov, N. P., Alekseev, A. D. (eds.) Resources of the Antarctic zone of the ocean and problems of their rational utilization. YugNIRO (Southern Scientific Research Institute Marine Fisheries and Oceanography) Press, Kerch, p. 113-114 (in Russian)

Cockcroft, V. G., Peddemors, V. M., Ryan, P. G., Lutjeharms, J. R. E. (1990). Cetacean sightings in the Agulhas Retroflection, Agulhas Rings and Subtropical Convergence. S. Afr. J. Antarct. Res. 20: 64-67

Comiso, J. C., McClain, C. R., Sullivan, C. W., Ryan, J. P. Leonard, C. L. (1993). Coastal zone color pigment concentrations in the Southern Ocean and relationships to geophysical surface features. J. geophys. Res. 98: 2419-2451

Davis, C. S., Wiebe, P. M. (1985). Macrozooplankton biomass in a warm-core Gulf Stream ring: time series changes in size structure, taxonomic composition, and vertical distribution. $J$. geophys. Res. 90: 8871-8884

Deacon, G. E. R. (1982). Physical and biological zonation in the Southern Ocean. Deep Sea Res. 29: 1-15

Dolzhenkov, V. N. (1975). Zooplankton of Pacific sector of the Southern Ocean. Autoreferat of Ph.D. dissertation. TINRO (Pacific Scientific Research Institute Marine Fisheries and Oceanography) Press, Vladivostok, p. 1-24 (in Russian)

Dolzhenkov, V. N. (1982). Zoogeographic zonation of the surface waters in the Pacific sector of the Southern Ocean by macroplankton. In: Fauna and distribution notal and Antarctic crustaceans (Collected papers). DVNC AN USSR (Dalnevostochny Centre of Soviet Union Academy Science) Press, Vladivostok, p. 11.0-116 (in Russian)

El-Sayed, S. Z. (1988). Seasonal and interannual variabilities in Antarctic phytoplankton with reference to krill distribution. In: Sahrhage, D. (ed.) Antarctic Ocean and resources variability. Springer-Verlag, Berlin, p. 101-119

Foxton, P. (1966). The distribution and life history of Salpa thompsoni Foxton with observations on a related species Salpa gerlachei Foxton. Discovery Rep. 34:1-116

Fukuchi, M., Tanimura, A., Ohtsuka, H. (1985). Zooplankton community conditions under sea ice near Syowa Station, Antarctica. Mar. Sci 37: 518-528

Gordon, A. L., Lutjeharms, J. R. E., Grundlingh, M. L. (1987). Stratification and circulation at the Agulhas Retroflection Deep Sea Res. 34: 565-599

Grachev, D. G. (1991). Frontal zone influences on the distribution of different zooplankton groups in the central part Indian sector of the Southern Ocean. In: The ecology of commercial marine hydrobionts (Collected papers). TINRO (Pacific Scientific Research Institute Marine Fisheries and Oceanography) Press, Vladivostok, p. 19-21 (in Russian!

Hardy, A. C., Gunther, E. R. (1935), The plankton of the South Georgia whaling ground and adjacent waters. Discovery Rep. 11. 1-456

Hopkins, T L. (1971). Zooplankton standing crop in the Pacific sector of the Antarctic, Biology of the Antarctic Seas, Vol. 4. Antarct. Res. Ser, 17: 347-362

Hopkins, T L. (1985). The zooplankton community of Croker
Passage, Antarctic Peninsula. Polar Biol. 4: 161-170

Hopkins, I L. (1987). Midwater food web in McMurdo Sound, Ross Sea, Antarctica. Mar. Biol. 96: 93-106

Hopkins, T L., Lancraft, T M., Torres, J. J., Donnelly, J. (1993). Community structure and trophic ecology of zooplankton in the Scotia Sea marginal ice zone in winter (1988). Deep Sea Res. 40:81-105

Hopkins, T L., Torres, J. J., Lancraft, I M., Donnelly, J. (1989). AMERIEZ 1988: aspects of the ecology and physiology of zooplankton and micronekton in the vicinity of a winter ice edge. Antarct. J. U.S. 24: 163-164

Hosie, G. W. (1994). The macrozooplankton communities in the Prydz Bay region, Antarctica. In: El-Sayed, S. Z. (ed.) Southern Ocean ecology: the BIOMASS perspective. Cambridge Univ. Press, Cambridge, p. 93-123

Hosie, G. W., Stolp, M. (1989). Krill and zooplankton in the western Prydz Bay region, September-November 1985. Proc. natl Inst. Polar Res. Symp. Polar Biol. 2: 34-45

Huntley, M. E., Lopez, M. D. G., Karl, D. M. (1991). Top predators in the Southern Ocean: a major leak in the biological carbon pump. Science 253: 64-66

Jaccard, P. (1902). Lois de distribution florale dans la zone alpine. Bull. Soc. vaud. Sci. nat. 38: 69-130

Koubbi, P. (1993). Oeufs, larves et juveniles de poissons présents dans le plancton de la zone océanique entourant les îles Kerguelen. In: Duhamel, G. (ed.) Les rapports des campagnes à la mer: campagnes SKALP 1987 et 1988 aux iles Kerguelen a bord des navires 'SKIF' et 'KALPER' 93-01 IFRTP (Institut Français pour la Recherche et la Technologie Polaires), Paris, p. 113-126

Lancraft, T M., Hopkins, T. L., Torres, J. J., Donnelly, J. (1991). Oceanic micronektonic/macrozooplanktonic community structure and feeding in the ice covered Antarctic waters during the winter (AMERIEZ 1988). Polar Biol. 11. $157-167$

Lancraft, T. M., Torres, J. J., Hopkins, T L. (1989). Micronekton and macrozooplankton in the open waters near Antarctic ice edge zones (AMERIEZ 1983 and 1986). Polar Biol. 9: 225-233

Laubscher, R. K., Perissinotto, R., McQuaid, C. D. (1993). Phytoplankton production and biomass at frontal zones in the Atlantic sector of the Southern Ocean. Polar Biol. 13: $471-481$

Linkowski, T B. (1983). Electrona carlsbergi (Taning 1932) the principal component of a deep scattering layer in the Pacific sector of Antarctic Ocean. Polish Polar Res. 4: $71-78$

Lomakina, N. V. (1964). Euphausiids fauna (Euphausiacea) of the Antarctic and notal regions. In: Biological reports of the Soviet Antarctic Expedition 1955-58, Vol. 2. Nauka Press, Leningrad, p. 254-334 (in Russian)

Longhurst, A. R., Harrison, W. G. (1989). The biological pump: profiles of plankton production and consumption in the upper ocean. Prog. Oceanogr. 22: 47-123

Lutjeharms, J. R. E. (1985). Location of frontal systems between Africa and Antarctica: some preliminary results. Deep Sea Res. 32: 1459-1509

Lutjeharms, J. R. E. (1988). Meridional heat transport across the Sub-Tropical Convergence by a warm eddy. Nature 331: $251-254$

Lutjeharms, J. R. E., Lucas, M. I., Perissinotto, R. van Ballegooyen, R. C., Rouault, M. (1994). Oceanic processes at the Subtropical Convergence; report of research cruise SAAMES III. S. A.fr. J. Sci. (in press)

Lutjeharms, J. R. E., Walters, N. M., Allanson, B. R. (1985). Oceanic frontal systems and biological enhancement. In: Siegfried, W. R., Condy, P. R., Laws, R. M. (eds.) Antarctic 
nutrient cycles and food webs. Springer-Verlag, Berlin, p. $11-21$

Lutjeharms, J. R. E., Valentine, H. R. (1984). Southern Ocean thermal fronts south of Africa. Deep Sea Res. 31 $1461-1475$

Mackintosh, N. A. (1934). Distributıon of the macroplankton in the Atlantic sector of the Antarctic. Discovery Rep. 9: $65-160$

Mackintosh, N. A. (1973). Distribution of post-larval krill in the Antarctic. Discovery Rep. 36: 95-156

Marr, J. W. S. (1962). The natural history and geography of the Antarctic krill (Euphausia superba Dana). Discovery Rep. 33: 33-464

Maruyama, T, Toyoda, H., Suzuki, S. (1982). Preliminary report on the biomass of macroplankton and micronekton collected with a bongo net during the Umitaka Maru FIBEX cruise. Tr. Tokyo Univ. Fish. 5: 145-153

Maslennikov, V. V., Zozulja, S. A., Polonsky, V. E. (1990). Role of oceanographic factors in distribution of Electrona carlsbergi in the South Polar Frontal Zone. In: Yakovlev, V. N. (ed.) Resourses of the Antarctic zone of the ocean and problems of their rational utilization. VNIERX Press, Moscow, p. 99-101 (in Russian)

Miller, D. G. M. (1982a). Results of a combined hydroacoustic and midwater trawling survey of the Prince Edward Island group. S. Afr. J Antarct. Res 12: 3-10

Miller, D. G. M. (1982b). Results of a combined hydroacoustic and midwater trawling survey of the Gough Island group. S. Afr. J. Antarct. Res. 12: 17-22

Miller, D. G. M. (1985). Marine macro-plankton of two subantarctic islands. In: Siegfried, W. R., Condy, P. R., Laws R. M. (eds.) Antarctic nutrient cycles and food webs. Springer-Verlag, Berlin, p. 355-361

Muravjova, O. E. (1982). Peculiarities of distribution of the plankton in the regions of oceanic mountains in the Pacific sector of the Southern Ocean (mountain Gerakl), Collected papers, Vol. 2. MGI (Marine Hydrophysical Institute Ukrainian Academy Science) Press, Sevastopol, p. $48-49$ (in Russian)

Naumov, A. G., Zernova, V. V., Ivanov, Yu. A., Tareev, B. A. (1962). Frontal zones and biogeographical dividing by plankton of the surface water $(0-500 \mathrm{~m})$ in the southern part of the Pacific Ocean. Reports IO RAN (Shirshov Institute Oceanology Russian Academy Science) 58: 54-66 (in Russian)

Olson, D. B., Evans, R. H. (1986). Rings of the Agulhas. Deep Sea Res. 33: $27-42$

Pakhomov, E. A. (1989). Macroplankton distribution in the central part of the Indian Antarctic sector in summer of 1984-1986. Antarctica 28: 145-158 (in Russian)

Pakhomov, E. A. (1991). Antarctic macroplankton and the nutrition of coastal fishes. Autoreferat of Ph.D. dissertation. Shirshov Institute Oceanology Russian Academy Science, Moscow, p. 1-24 (in Russian)

Pakhomov, E. A. (1993a). Macroplankton of the waters contiguous to the Kerguelen Archipelago. In: Duhamel, G. (ed.) Les rapports des campagnes à la mer: campagnes SKALP 1987 et 1988 aux îles Kerguelen à bord des navires 'SKIF' et 'KALPER' 93-01. IFRTP (Institut Français pour la Recherche et la Technologie Polaires), Paris, p. 104-112

Pakhomov, E. A. (1993b). Feeding and daily ration assessment of the grey notothenia Notothenia squamifrons squamifrons on the banks Ob and Lena (Indian sector of Antarctica. J. Ichthyology 33: $407-416$ (in Russian)

Perissinotto, R, MCQuaid, C. D. (1992). Land-based predator impact on vertically migrating zooplankton and micronek-

This article was submitted to the editor ton advected to a Southern Ocean archipelago. Mar. Ecol. Prog. Ser. 80: 15-27

Piatkowski, U. (1987). Zoogeographische Untersuchungen und Gemeinschaftsanalysen an antarktischem Makroplankton. Ber. Polarforsch. 34: 1-150

Piatkowski, U. (1993). Preliminary list of the cephalopod fauna from the upper oceanic layers of the Kerguelen Islands during the 'Skif' cruises (February 1987 to March 1988). In: Duhamel, G. (ed.) Les rapports des campagnes à la mer: campagnes SKALP 1987 et 1988 aux îles Kerguelen à bord des navires 'SKIF' et 'KALPER' 93-01 IFRTP (Institut Français pour la Recherche et la Technologie Polaires), Paris, p. 127-134

Pommeranz, T., Herrmann, C., Kuhn, A. (1982). Mouth angles of the Rectangular Midwater Trawl (RMT 1+8) during paying out and hauling. Meeresforsch. 29: 267-274

Robertson, A. A., Alexander, D. G. W. Miller, D. G. M. (1981). Modified collapsible opening and closing midwater trawls (RMT-8 and RMT-2). Fish. Bull. S. Afr. 14: 103-113

Roe, H. S. J., Baker, A. de C., Carson, R. M., Wild, R., Shale, D. M. (1980). Behaviour of the Institute of Oceanographic Science's rectangular midwater trawls: theoretical aspects and experimental observations. Mar. Biol 56: 247-259

Rustad, D. (1930). Euphausiacea with notes on their biogeography and development. Sci. Res. Norw. Antarct. Exped. 5: $1-83$

Semelkina, A. N. (1993). Development of the zooplankton in the Kerguelen Islands region in the years 1987-88. In: Duhamel, G. (ed.) Les rapports des campagnes à la mer: campagnes SKALP 1987 et 1988 aux îles Kerguelen à bord des navires 'SKIF' et 'KALPER' 93-01. IFRTP (Institut Français pour la Recherche et la Technologie Polaires), Paris, p. 90-103

Siegel, V., Piatkowski, U. (1990). Variability in the macrozooplankton community off the Antarctic Peninsula. Polar Biol. 10: 373-386

Siegel, V., Skibowski, A., Harm, U. (1992). Community structure of the epipelagic zooplankton community under the sea-ice of the northern Weddell Sea. Polar Biol. 12: 15-24

Shuntov, V. P., Kirlan, D. F., Batytskaja, D. V., Glebova, S. Ju., Kolesova, N. G. (1982). Regions of high concentrations of different groups of birds, abundance and their interannual changes in the Southern Ocean. Biologia morja 3: 3-11 (in Russian)

Tanimura, A., Fukuchi, M., Hoshiai, T (1986). Seasonal change in the abundance of zooplankton and species composition of copepods in the ice-covered sea near Syowa Station, Antarctica. Mem. Natl. inst Polar Res. 40: 212-220

Tuker, M. J, Burton, H. R. (1990). Seasonal and spatial variations in the zooplankton community of an eastern Antarctic coastal location. Polar Biol. 10: 571-579

Vinogradov, M. E., Volkov, A. F., Semenova, T N. (1982). Hyperiids (Amphipoda, Hyperiidea) of the Ocean. Nauka Press, Leningrad, p. 1-492 (in Russian)

Voronina, N. M. (1984). Pelagic ecosystems of the Southern Ocean. Nauka Press, Moscow, p. 1- 206 (in Russian)

Weeks, S. J., Shillington, F. A. (1994). Interannual scales of variation of pigment concentrations from coastal zone color scanner data in the Benguela Upwelling system and the Subtropical Convergence zone south of Africa. J. geophys. Res. 99(C4): 7385-7399

Zemsky, A. V. (1987). Studies of the mass myctophid species in the east area of the Antarctic Pacific sector In: Makarov, R. R. (ed.) Biological-oceanographic investigations in the Pacific sector of the Southern Ocean. VNIRO Press, Moscow, p. 193-201 (in Russian)

Manuscript first received: December 6, 1993

Revised version accepted: May 18, 1994 